\title{
Sustainable Development in the Smart Growth Cities
}

\author{
Lingqing Zhao \\ North China Electric Power University \\ 876524856@qq.com
}

\section{Keywords: Smart growth; Sustainable developmen; Three E; Entropy method}

\begin{abstract}
Urbanization is becoming the general trend of the whole world. In this paper, we aim to find an ultimate strategy for all countries that can not only achieve the goal of normal urbanization, but also meet the policy of sustainable development. What is necessary to emphasize is that we establish our models in accordance with the rule of smart growth and three E. With the help of the models, we finally conclude a reliable and stable plan to promote the smart growth to cities. Our paper is to obtain an indicator to measure a city's success rate of smart growth. We build an evaluation system called "S-C" and define $\mathrm{S}$ as the indicator to measure the success rate of smart growth which is determined by eleven factors mentioned at the first problem. Furthermore, The first model based on entropy method is established according to multiple factors . We calculate scores of each factor and multiply them with their own proportion to obtain $\mathrm{S}$. At the same time, we define $\mathrm{C}$ as the coordination of measuring a city's smart growth based on three E. Finally, $\mathrm{C}$ is obtained through coupling, coordinating and calculating after obtaining the three E .
\end{abstract}

\section{Introduction}

\section{Background.}

According to the statistics, the global urban population exceeded the global rural population for the first time in history in $2007^{[1]}$ and as the prediction says, the process of urbanization will continue to be rapid in the near future. However, a series of crises are coming, such as decreasing of cultivable plow, overloading of the environment, low efficient of development, lagging behind of basic facilities and so on. In consideration of the sustainable development as our development goal, many communities are implementing smart growth whose basic idea is the compact land use[2].

\section{Restatement of the Problem.}

Smart growth is a composite plot of city development that includes a a number of aspects. Using this plot, cities can solve problems in the condition of the tension of cultivated land resources, the high speed of urbanization and economy developing fast in their process of development. We can provide a reliable theoretical basis for cities after building a efficacious evaluation system based on the smart growth.

\section{Notations and definitions}

Table 1 Notations

\begin{tabular}{ll}
\hline Symbols & Meanings \\
\hline $\mathrm{x}_{\mathrm{ij}}$ & Data of year i under factor $\mathrm{j}$ \\
$\mathrm{y}_{\mathrm{ij}}$ & Proportion of year i under factor $\mathrm{j}$ \\
$\mathrm{e}_{\mathrm{i}}$ & Information entropy of factor $\mathrm{j}$ \\
$\mathrm{d}_{\mathrm{j}}$ & The redundancy of information entropy of factor $\mathrm{j}$ \\
$\mathrm{w}_{\mathrm{i}}$ & Weight of factor $\mathrm{j}$ \\
$\mathrm{u}_{\mathrm{ij}}$ & Score of single factor \\
$\mathrm{S}$ & Evaluation value of factors \\
$\mathrm{C}_{0 i}$ & Factors that influence the ten principle of smart growth \\
$\mathrm{C}$ & Coordination of 3E development \\
$\rho$ & Resolution coefficient of association analysis \\
$\gamma_{i}$ & Association degree of series $x_{\mathrm{i}}$ to series $x_{0}$ \\
$\zeta_{\mathrm{i}(k)}$ & The association coefficient of series $x_{\mathrm{i}}$ to series $x_{0}$ at time $\mathrm{k}$ \\
\hline
\end{tabular}




\section{Assumptions}

- There's no major natural disaster of the selected area in the past decade and in two decades.

- We assume that the factors we have taken into account influence so greater that we can neglect any others.

- The regions we related to won't have any financial crisis in twenty years.

- The factors we take account into can reflect the ten principles for smart growth .

\section{The Establishment And Solution of The Model}

\section{The Establishment of the Model I.}

We establish the first model called "the success rate of smart growth model" based on the the ten principles for smart growth.

Considering that the the ten principles can't quantify the data to some extent, we choose eleven factors to epitomize(table 2. ) the the ten principles and establish the model.

Table 2. Metric to measure the success of smart growth of a city

\begin{tabular}{|c|c|c|c|c|c|}
\hline Target layer (A) & \multicolumn{2}{|c|}{ Factor layer（C） } & Unit & $\begin{array}{l}\text { reflecting of smart growth } \\
\text { principles }\end{array}$ & effect \\
\hline \multirow{11}{*}{$\begin{array}{l}\text { metric to measure the } \\
\text { success of smart } \\
\text { growth of a city }\end{array}$} & $\mathrm{C} 01$ & $\begin{array}{l}\text { proportion of } \\
\text { urban population }\end{array}$ & $\%$ & $\begin{array}{c}\text { Strengthen and direct } \\
\text { development towards existing } \\
\text { communities }\end{array}$ & + \\
\hline & $\mathrm{C} 02$ & $\begin{array}{l}\text { net income of rural } \\
\text { areas per capita }\end{array}$ & - & $\begin{array}{l}\text { Encourage community and } \\
\text { stakeholder collaboration in } \\
\text { development decisions }\end{array}$ & + \\
\hline & $\mathrm{C} 03$ & traffic accessibility & - & $\begin{array}{c}\text { Provide a variety of transportation } \\
\text { choices }\end{array}$ & + \\
\hline & $\mathrm{C} 04$ & $\begin{array}{l}\text { agricultural area } \\
\text { per capita }\end{array}$ & person $/ \mathrm{Km}^{2}$ & $\begin{array}{c}\text { Preserve open space, farmland, } \\
\text { natural beauty, and critical } \\
\text { environmental areas }\end{array}$ & + \\
\hline & $\mathrm{C} 05$ & $\begin{array}{l}\text { rural settlement } \\
\text { per capita }\end{array}$ & $\mathrm{Km}^{2} /$ person & $\begin{array}{l}\text { Take advantage of compact } \\
\text { building design }\end{array}$ & - \\
\hline & $\mathrm{C} 06$ & $\begin{array}{l}\text { population density } \\
\text { in } \mathrm{Km}^{2}\end{array}$ & person $/ \mathrm{Km}^{2}$ & $\begin{array}{l}\text { Foster distinctive, attractive } \\
\text { communities with a strong sense } \\
\text { of place }\end{array}$ & - \\
\hline & $\mathrm{C} 07$ & $\begin{array}{l}\text { annual } \\
\text { precipitation }\end{array}$ & year/mm & $\begin{array}{c}\text { Preserve open space, farmland, } \\
\text { natural beauty, and critical } \\
\text { environmental areas }\end{array}$ & + \\
\hline & $\mathrm{C} 08$ & water areas & $\mathrm{Km}^{2}$ & $\begin{array}{c}\text { Preserve open space, farmland, } \\
\text { natural beauty, and critical } \\
\text { environmental areas }\end{array}$ & + \\
\hline & $\mathrm{C} 09$ & $\begin{array}{l}\text { proportion of } \\
\text { wooden areas }\end{array}$ & $\%$ & $\begin{array}{c}\text { Preserve open space, farmland, } \\
\text { natural beauty, and critical } \\
\text { environmental areas }\end{array}$ & + \\
\hline & $\mathrm{C} 10$ & $\begin{array}{l}\text { proportion of dry } \\
\text { land areas }\end{array}$ & $\%$ & $\begin{array}{c}\text { Preserve open space, farmland, } \\
\text { natural beauty, and critical } \\
\text { environmental areas }\end{array}$ & + \\
\hline & $\mathrm{C} 11$ & $\begin{array}{l}\text { cultivated land } \\
\text { loss index }\end{array}$ & - & $\begin{array}{c}\text { Preserve open space, farmland, } \\
\text { natural beauty, and critical } \\
\text { environmental areas }\end{array}$ & - \\
\hline
\end{tabular}


Based on the factors chosen, we set factors' matrix to be ( $x_{i j}$ is the value of factor $j$ of plan $\left.i\right)$ :

$$
\mathrm{A}=\left(\begin{array}{ccc}
x_{11} & \cdots & \mathrm{x}_{1 m} \\
\vdots & \ddots & \vdots \\
x_{n 1} & \cdots & x_{n m}
\end{array}\right)_{n \times m}
$$

About the Data Normalization.

For positive factors:

$$
x_{i j}^{\prime}=\frac{x_{i j}-\min \left\{x_{j}\right\}}{\max \left\{x_{j}\right\}-\min \left\{x_{j}\right\}}
$$

For negative factors:

$$
x_{i j}^{\prime}=\frac{\max \left\{x_{j}\right\}-x_{i j}}{\max \left\{x_{j}\right\}-\min \left\{x_{j}\right\}}
$$

Therefore, we can calculate the proportion $\mathrm{y}_{\mathrm{ij}}$ of country $i$ under factor $j$ :

$$
y_{i j}=\frac{x_{i j}^{\prime}}{\sum_{i=1}^{m} x_{i j}^{\prime}}
$$

(4)

We set $e_{j}$ asinformation entropy of factor $j$, the equation is shown below:

$e_{i}=-k \sum_{i=1}^{m}\left(y_{i j} \times \ln y_{i j}\right)$

Then we use $d_{j}=1-e_{j}$ to directly compute thecontribution rate of factorj's weight. We can obtain the weight of factorjfrom the equation below:

$$
w_{j}=\frac{d_{j}}{\sum_{j=1}^{n} d_{j}}
$$

To obtain the score of single factor:

$\mathrm{u}_{i j}=w_{j} \times x_{i j}^{\prime}$

(7)

Finally, we use weighted summation formula to calculate $U$ :

$$
S=\sum_{i=1}^{n} y_{i j} \times w_{j}
$$

\section{The Establishment of the Model II.}

At the same time, we lead the concepts of coordination degree and coupling degree in in order to evaluate coordinated development in the condition of adhere to the three E's.

Coordination degree: It is a measure of the system or system elements within the development process in harmony with each other, reflecting the trend of the system from disorder to order. which is the quantitative factor that coordinate the extent of good or bad. ${ }^{[5]}$ 
We divide the evaluation system into three levels:target layer、criteria layer and criteria layer. The rule of identifying these factors are:

Try to choose representativefactors which can reflect in the degree of system coordination;

In order to avoid the area's effect of one region, we choose relative factors per capita as possible;

Choose factors which are easy to check to the greatest extent;

Try to choose the positive factors.

The model IIcalled "the evaluation model based on Coordination level of 3E"can obtain the coordination degree of the economically prosperous, socially equitable and environmentally sustainable easily. In the process of establishing the model, we first classify the factors into three groups respectively corresponding to three $\mathrm{E}$ :

Agricultural area per capita, rural settlement per capita and population density in $\mathrm{Km}^{2}$ in the group of "socially equitable"; proportion of urban population, net income of rural areas per capita and traffic accessibility in the group of "economically prosperous" ;annual precipitation , water areas , proportion of dry land areas and cultivated land loss index in the group of "environmentally sustainable".

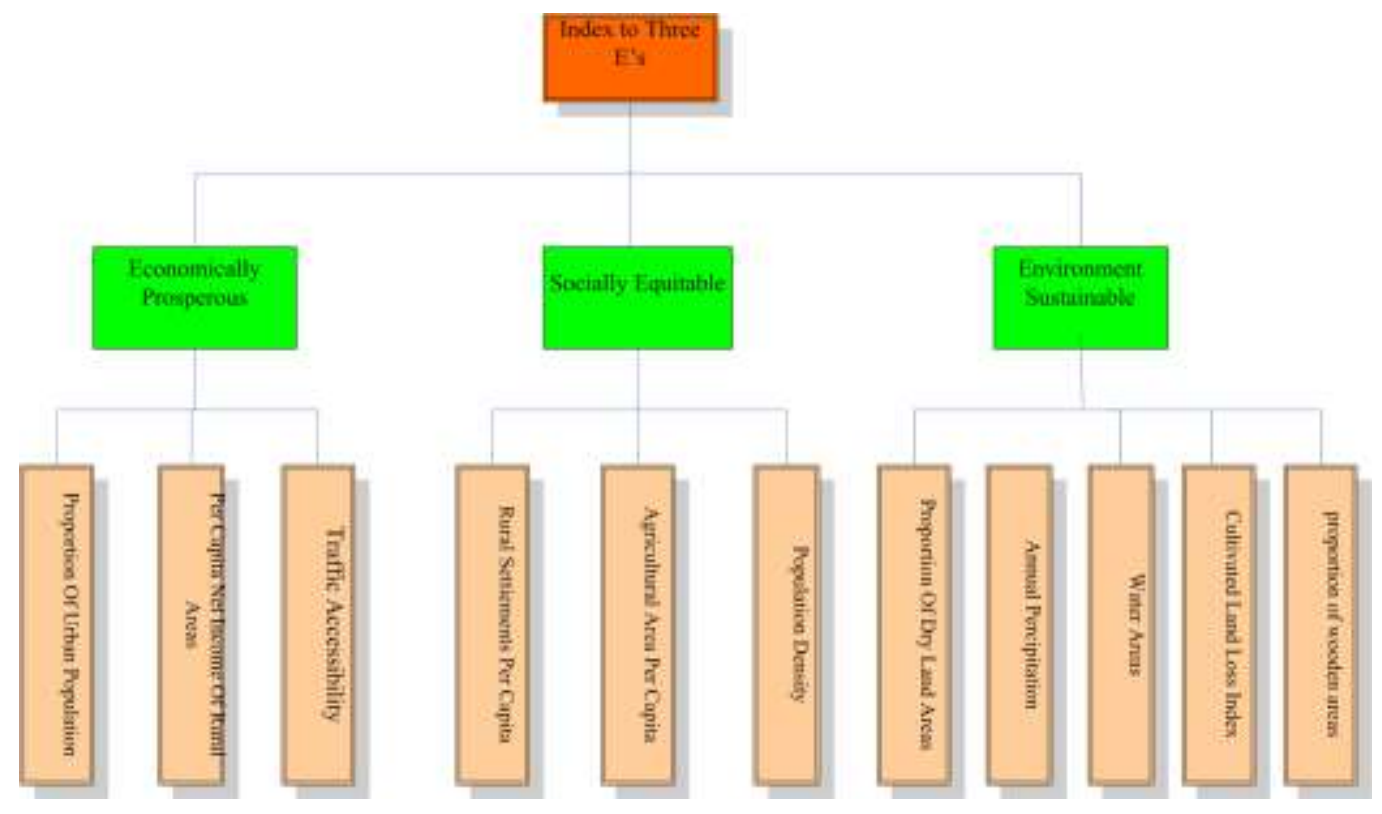

Figure 1. Classification results of factors

Then we standardize the factors and obtain their own proportions and record them as $k_{i}$. We define the weight of three E:

$$
\begin{aligned}
& F_{1}=\frac{1}{3} \times\left(k_{1}+k_{2}+k_{3}\right) \\
& F_{2}=\frac{1}{3} \times\left(k_{4}+k_{5}+k_{6}\right) \\
& F_{3}=\frac{1}{5} \times\left(k_{7}+k_{8}+k_{9}+k_{10}+k_{11}\right)
\end{aligned}
$$

Thus:

$$
F_{i}=\frac{1}{n} \sum_{i=1}^{n} C_{i}
$$

To reflect the coordination degree, we define: 


$$
C=\sqrt{\frac{1}{n} \sum_{i=1}^{n}\left(F_{i}-F\right)^{2}}
$$

Table 3 The degree of coordination

\begin{tabular}{|l|l|l|l|}
\hline$C$ & $<0.1$ & $0.1-1.0$ & $>1.0$ \\
\hline $\begin{array}{l}\text { Coordination } \\
\text { degree }\end{array}$ & Good & Normal & Bad \\
\hline
\end{tabular}

\section{Result of the Models.}

Based on the analysis above, we choose thirty countries that are different form each other on the development level from two continents and then collect related data. After ranking, we obtain the factor of smart growth's success rate.

Table 4 Description of Classifying ${ }^{[6]}$

\begin{tabular}{|c|c|c|}
\hline Level & Level's Name & Level Description \\
\hline $\mathrm{I}$ & $\begin{array}{l}\text { High-smart } \\
\text { utilization }\end{array}$ & $\begin{array}{l}\text { Many kinds of factors' values are high while low value } \\
\text { entries are a few. The traffic accessibility is good. The } \\
\text { ecological condition is well protected. Land are mixed } \\
\text { used. All in all, the society, ecology and economy are } \\
\text { developing in a high degree of coordination. Regional land } \\
\text { use is at a stage of smart growth. }\end{array}$ \\
\hline II & $\begin{array}{l}\text { Low-smart } \\
\text { utilization }\end{array}$ & $\begin{array}{l}\text { Many kinds of factors' value are at intermediate level while } \\
\text { there is high value entry. The traffic accessibility } \\
\text { isrelatively good. The ecological is partly polluted but can } \\
\text { return to normal in a short time. Land use is moderate . } \\
\text { Regional land use is at a stage of smart growth in general. }\end{array}$ \\
\hline III & $\begin{array}{l}\text { High-spreading } \\
\text { utilization }\end{array}$ & $\begin{array}{l}\text { Many kinds of factors' value are at intermediate level while } \\
\text { there is low value entry. Location advantage is not obvious. } \\
\text { The protection of environment lags. The efficiency of } \\
\text { land utilization is low. Economic development is slow. } \\
\text { Regional land use is at a stage of low spreading. }\end{array}$ \\
\hline IV & $\begin{array}{l}\text { Low-spreading } \\
\text { utilization }\end{array}$ & $\begin{array}{l}\text { Many kinds of factors' value are low. while high value } \\
\text { entries are a few. The efficiency of land utilization is } \\
\text { extremely low. The environment is destroyed severely. } \\
\text { Regional land use is at a stage of spreading. }\end{array}$ \\
\hline
\end{tabular}

Table 5 The relation between factorand the level of smart growth's success rate

\begin{tabular}{lllll}
\hline & $\mathrm{I}$ & $\mathrm{II}$ & $\mathrm{III}$ & $\mathrm{IV}$ \\
\hline Level & $>70 \%$ & $40 \%-70 \%$ & $15 \%-40 \%$ & $<15 \%$ \\
\hline
\end{tabular}

\section{References}

[1] EPA, "Smart Growth: A Guide to Developing and Implementing Greenhouse Gas Reductions Programs.”2011.http://www.sustainablecitiesinstitute.org/Documents/SCI/Report_Guide/Guide _E PA_SmartGrowthGHGReduction_2011.pdf

[2] ZhanfuLuo :Study on the Urban Spatial Expansion from Smart Growth Angle. 2009. 5

[3] https://www.bfs.admin.ch/bfs/en/home/statistics/cross-sectional-topics/city-statistics/city-portra 
its/lausanne. html

[4] http://www. gso. gov. vn/Default_en. aspx?tabid=766

[5] http://baike.baidu.com/link?url=loQhoG1o4feaR3jtUGImy1ouNKS6L_xpR8ptDbTR14p-dWK MD5gvRyzdUdEULUjgeEbXuqc_I8fZ62rrEWysaZ5IftN3K4sfUCEWA7LNE13KGZIE10NTa Y-Ro4oT3rrE

[6] Long Jing :Study on the Use of smart Growth of Urban and Rural Land Based on BP Artificial Neural Network. 2013. 6

[7] Pei Shifangcao: Research on Learning CHANG-ZHU-TAN's Experience of VIETNAM Urban Development Pattern. 2014. 5

[8] https://www. wenku. baikdu. 2013. 8.5

[9] https://www. caexpo. com 2012-11-12

[10] https://en. wikipedia. org/wiki/Lausanne 